Bangl. J. Vet. Med. (2011). 9 (2) : $145-153$

\title{
RETROSPECTIVE EPIDEMIOLOGIC STUDY OF DISEASES IN RUMINANTS IN KHAGRACHARI HILL TRACT DISTRICT OF BANGLADESH
}

\author{
M. H. Ali ${ }^{1}$, M. K. J. Bhuiyan ${ }^{2}$ and M. M. Alam ${ }^{1}$ \\ ${ }^{1}$ Department of Medicine, Faculty of Veterinary Science, Bangladesh Agricultural University, Mymensingh \\ ${ }^{2}$ Department of Agricultural Statistics, Bangladesh Agricultural University, Mymensingh
}

\begin{abstract}
A retrospective epidemiologic study of animal diseases was undertaken at Khagrachari Sadar Veterinary Hospital during January, 2006 to December, 2010 to determine prevalence and distribution of animal diseases. According to the diseases register, a total of 3988 sick animals were examined and 53 types of diseases were identified during this period. The commonly found various diseases were worm infestation (51.5\%), pneumonia and pneumonitis (7.9\%), ephemeral fever (3.7\%), enteritis (3.4\%), mastitis(3.2\%), mange (3.2\%), indigestion (2.8\%), anestrous(2.6\%). Rest of the diseases had lower percentage than $2 \%$. Out of 3988 sick animals, $74.7 \%$ were female and $25.3 \%$ were male animals. Animals aged between $2-5$ (A1) years had high prevalence (54.0\%) and it was low in age group 8-10 years (A4), 2.4\%. Prevalence of diseases was high $(42.3 \%)$ in rainy season (June-October) followed by (32.5\%) in winter (November-February) and lowest (25.2\%) in summer season (March-May). Gastrointestinal diseases $61.6 \%$ (2458 cases) was seen highly prevalent among all groups of animals which was followed by infectious diseases $10.4 \%$ (416 cases), skin diseases $9.4 \%$ (377 cases), respiratory diseases $8.27 \%$ (330 cases) and reproductive diseases $7.93 \%$ (cases). This study suggests that for a period of 15 years or more will help to identify the risk factors of diseases in this area.
\end{abstract}

Key words: Retrospective study, Epidemiology, Diseases, Ruminants

\section{INTRODUCTION}

The magnitude of contribution of the livestock sector to the GDP is $2.6 \%$ in Bangladesh and $80 \%$ rural people rear indigenous animals. The present population of cattle, goat, sheep and pig are 22970000, 22400000, 2870000 and 100000 respectively (DLS, 2010). Livestock sector provides full time employment to approximately 20\% and part time employment to approximately $50 \%$ of the rural population of Bangladesh. It also generates an adequate amount of foreign currency every year by exporting hides and skin and their products. Besides, per capita income of Bangladesh is 750 US dollar and $49 \%$ of the total population of Bangladesh is malnourished. Per capita requirement of protein can not be fulfilled by our protein sources. So, continuous protein deficiency causes various nutritional deficiency diseases followed by infectious diseases and reproductive disturbances. If the livestock sector develops, it will be able to fulfill the existing requirement of protein for the country. Approximately $36 \%$ protein requirement is fulfilled by livestock sector.

In the rural area of Plain land of Bangladesh livestock rearing such as beef fattening, goat rearing, buck rearing and sheep rearing are gradually increasing day by day. But in hill tract area of Bangladesh livestock rearing is not well established though there is a great prospect in hilly tracts. Red Chittagong cattle are more sustainable in Chittagong hill tract area. The goat is called the "Poor man's cow" is the second important livestock in Bangladesh which plays an important role in the rural economy and earn substantial amount of foreign currency by exporting skin and others byproducts (Kamaruddin, 2003). Each year goat production provides 127,000 MT meat, which accounts for $25 \%$ of total red meat in Bangladesh (FAO, 2007). Even in urban area goats are being raised under an intensive system of management by stall feeding with bran, fodder and tree leaves. Pig rearing is very uncommon in plain land area but there exists a great scope of pig rearing in hill tracts area (Khagrachari, Rangamati and Bandarban districts) as pig rearing and pork are very interesting to trivals people. There is government pig farm in Rangamati hill tracts district. Diseases of pig is less common in Bangladesh as their population is very small, but swine erysipelas is a diseases causing great harm in all ages of animals all the year round.

*Corresponding e-mail address: jamanbau@yahoo.com 


\section{H. Ali and Others}

There exists a variety of problems in livestock sector of Bangladesh such as insufficient pasture land, lack of technical expert, insufficient supply of vaccine, lack of epidemiologic study and shortage of government employee in the field level and various diseases of different systems of animals. Among various problems, diseases play an important role interfering with the development of healthy livestock and livestock industry in our country. Infectious diseases cause a great harm in livestock. It has been estimated that about $10 \%$ animals die annually due to diseases. Disease also causes nutritional deficiency and disturbances in fertility.

Understanding on the incidence, prevalence, distribution and determinants or risk factors of diseases in an area is necessary for undertaking efficient control program. Studying diseases of animals retrospectively is a rapid and cheap means to identify the strategy of effective disease control when it is analyzed statistically. Therefore, a retrospective study was carried out to elucidate the epidemiology of diseases in domestic animals.

\section{MATERIALS AND METHODS}

\section{Selection of Research Site}

The retrospective epidemiologic study of diseases in ruminants was done using of 5 years data in Khagrachari sadar Upazila Veterinary Hospital of Khagrachari Hill tract district.

\section{Sources and Nature of Data}

The retrospective data of 5 years from January 2006 to December 2010 were collected from patient register of Veterinary Hospital, Khagrachari sadar, Khagrachari maintained by veterinary surgeon. The data were analyzed retrospectively and interpreted to determine the prevalence of diseases; seasonal pattern and distribution of diseases. The age, sex, and body weight of the animals were collected from the register.

\section{Data Processing}

The data were checked manually for obvious inconsistencies, recording errors or missing data. The potential errors were evaluated and corrected. Data with suspicious values were excluded. Data were statistically analyzed by Statistical Package for Social Science (SPSS) software 17.0 version. Chi-square test was used to know the association between different groups in respective cases. According to age, diseased animals were grouped as 02, 2-5, 5-8 and 8-10 years. We considered three seasons as Summer from March to May, Rainy from June to October and Winter from November to February. During the period of study 3988 diseased animals were recorded from patient register. Among them 934 cases (23.4\%) were cow, 180 cases (4.5\%) were bull, 598 cases (15.0\%) were heifer, 487 cases (12.2\%) were calf, 1403 cases (35.2\%) were goat, 45 cases (1.1\%) were sheep and 341 cases (8.6\%) were pig. Out of the total cases 1010 cases (25.3\%) were male and 2978 cases $(74.7 \%)$ were female. Male and female animal's ratio was 1:3 approximately.

\section{RESULTS AND DISCUSSION}

Age, sex and season wise distribution of diseases and disorders observed in different systems of cattle

The diseases and disorders observed in the different systems of cattle are shown in the Table 1-4. In the study 3938 ruminants were studied where cattle were 2199 and out of 53 detected diseases about 45 diseases were observed in case of cattle (Table1). In the study it was found that cattle of different aged were significantly suffering from various diseases and disorders, where maximum no. of cattle (1171) were affected by worm infestation. The study also revealed that most of cattle of all studied aged were affected with gastrointestinal diseases (Table $1 \& 2$ ). It was exerted from the study that only two numbers of deficiency \& metabolic diseases (Agalactia and Milk fever) as well as three numbers of diseases related to sense organs (corneal opacity, Keratitis and Otitis) were found from the studied cattle during the period 2006-2010 in the Khagrachari hill tract district of Bangladesh. Dog bite was recorded as single case. Results acquired from the study that worm infestation was more frequent in all the studied aged of cattle as compared with other diseases and disorders. The study also gave interesting phenomena that $42.22 \%$ of cattle were suffering from 10 or less enlisted diseases and disorders whereas $20 \%$ of cattle were suffering from only one kind of diseases.

Table $1 \& 2$ also expressed that cattle of 0 - 2 years old were mostly significantly susceptible to diseases and disorders in contrast of cattle of other studied aged.

Sex wise diseases and disorders in cattle were presented in the Table $1 \& 3$. The study revealed that female cattle were significantly affected with diseases and disorder observed in the different systems of cattle where as male responded as minimum ones (Table $1 \& 4$ ). Likely the trend of age based phenomena, worm infestation was also ranked as the most frequent in case of female in the studied hill areas may be due to less attention against preventing 
measures of worm. In the study some diseases such as dysentery, fasciliosis, arthritis, wound and corneal opacity were not identified from male, which is favorable for profitable cattle rearing in hill area. It can also be stated that male cattle were more prominent against dog bite as compared to female ones (Table 1).

Table 1. Distribution of diseases and disorders in Cattle observed in age, sex and season wise

\begin{tabular}{|c|c|c|c|c|c|c|c|c|c|c|}
\hline \multirow{2}{*}{$\begin{array}{l}\text { Diseases occurred in } \\
\text { the different systems }\end{array}$} & \multicolumn{4}{|c|}{ Age Grouping (Year) } & \multicolumn{2}{|c|}{ Sex } & \multicolumn{3}{|c|}{ Season } & \multirow[b]{2}{*}{ Total } \\
\hline & $\begin{array}{l}0-2 \\
\left(A_{1}\right)\end{array}$ & $\begin{array}{l}2-5 \\
\left(A_{2}\right)\end{array}$ & $\begin{array}{l}5-8 \\
\left(A_{3}\right)\end{array}$ & $\begin{array}{l}8-10 \\
\left(\mathrm{~A}_{4}\right)\end{array}$ & $\mathrm{M}$ & $\mathrm{F}$ & Summer & Rainy & Winter & \\
\hline \multicolumn{11}{|c|}{ Gastrointestinal system } \\
\hline Bloat & 0 & 2 & 9 & 0 & 2 & 10 & 4 & 4 & 3 & 11 \\
\hline Dysentery & 0 & 0 & 1 & 0 & 0 & 1 & 0 & 0 & 1 & 1 \\
\hline Enteritis & 25 & 41 & 22 & 0 & 25 & 63 & 6 & 48 & 34 & 88 \\
\hline Fasciliosis & 1 & 6 & 0 & 0 & 0 & 7 & 0 & 0 & 7 & 7 \\
\hline Indigestion & 47 & 1 & 21 & 11 & 46 & 33 & 18 & 25 & 37 & 80 \\
\hline Tympany & 0 & 41 & 5 & 5 & 43 & 8 & 14 & 19 & 18 & 51 \\
\hline Worm infestation & 657 & 275 & 197 & 47 & 123 & 1048 & 308 & 505 & 359 & 1171 \\
\hline Total & 730 & 366 & 255 & 53 & 239 & 1170 & 350 & 601 & 459 & 1410 \\
\hline \multicolumn{11}{|l|}{ Respiratory system } \\
\hline Aspiration pneumonia & 9 & 2 & 0 & 0 & 1 & 10 & 3 & 2 & 6 & 11 \\
\hline Pneumonia & 12 & 0 & 0 & 0 & 2 & 10 & 5 & 0 & 7 & 12 \\
\hline Pneumonitis & 27 & 0 & 0 & 0 & 8 & 19 & 10 & 7 & 10 & 27 \\
\hline Total & 48 & 2 & $\mathbf{0}$ & $\mathbf{0}$ & 11 & 39 & 18 & 9 & 23 & 50 \\
\hline \multicolumn{11}{|l|}{ Reproductive system } \\
\hline Abortion & 0 & 1 & 0 & 1 & 0 & 2 & 0 & 0 & 2 & 2 \\
\hline Anestrous & 1 & 102 & 0 & 0 & 0 & 103 & 30 & 37 & 36 & 103 \\
\hline Cervicitis & 0 & 14 & 0 & 0 & 0 & 14 & 6 & 3 & 5 & 14 \\
\hline Mastitis & 4 & 61 & 24 & 0 & 0 & 89 & 17 & 41 & 31 & 89 \\
\hline Mentritis & 0 & 2 & 0 & 0 & 0 & 2 & 1 & 0 & 1 & 2 \\
\hline Posthitis & 0 & 1 & 0 & 0 & 1 & 0 & 0 & 1 & 0 & 1 \\
\hline Retention of placenta & 0 & 2 & 0 & 0 & 0 & 2 & 0 & 0 & 2 & 2 \\
\hline Vaginitis & 0 & 5 & 0 & 0 & 0 & 5 & 0 & 4 & 1 & \\
\hline Dystocia & 0 & 0 & 4 & 0 & 0 & 1 & 4 & 0 & 0 & 4 \\
\hline Total & 5 & 188 & 28 & 1 & 1 & 218 & 58 & 86 & 78 & 219 \\
\hline \multicolumn{11}{|l|}{ Musculosketal system } \\
\hline Arthritis & 1 & 0 & 0 & 0 & 0 & 1 & 0 & 0 & 1 & 1 \\
\hline Broken horn & 1 & 0 & 0 & 0 & 1 & 0 & 0 & 0 & 1 & 1 \\
\hline Yoke gall & 0 & 17 & 0 & 0 & 15 & 2 & 5 & 9 & 3 & 17 \\
\hline Total & 2 & 17 & $\mathbf{0}$ & $\mathbf{0}$ & 16 & 3 & 5 & 9 & 5 & 19 \\
\hline \multicolumn{11}{|l|}{ Integumentary system } \\
\hline Abcess & 5 & 0 & 0 & 0 & 0 & 5 & 0 & 1 & 4 & 5 \\
\hline Hump sore & 0 & 1 & 0 & 0 & 1 & 0 & 0 & 1 & 0 & 1 \\
\hline Hypotrycosis & 28 & 0 & 0 & 0 & 6 & 22 & 8 & 13 & 7 & 28 \\
\hline Lice infestation & 33 & 0 & 0 & 27 & 12 & 48 & 10 & 24 & 26 & 60 \\
\hline Udder edema & 0 & 8 & 0 & 0 & 0 & 8 & 2 & 2 & 4 & 8 \\
\hline Urticaria & 11 & 1 & 0 & 0 & 9 & 3 & 5 & 3 & 4 & 12 \\
\hline Wound & 1 & 0 & 0 & 0 & 0 & 4 & 1 & 0 & 0 & 1 \\
\hline Total & 78 & 10 & $\mathbf{0}$ & 27 & 28 & 90 & 26 & 44 & 45 & 118 \\
\hline \multicolumn{11}{|c|}{ Disease of sense organs } \\
\hline Corneal opacity & 0 & 1 & 0 & 0 & 0 & 1 & 0 & 0 & 1 & 1 \\
\hline Keratitis & 1 & 0 & 0 & 0 & 1 & 0 & 0 & 1 & 0 & 1 \\
\hline Otitis & 0 & 0 & 0 & 14 & 12 & 2 & 3 & 7 & 4 & 14 \\
\hline Total & 1 & 1 & $\mathbf{0}$ & 14 & 13 & 3 & 3 & 8 & 5 & 16 \\
\hline
\end{tabular}




\section{H. Ali and Others}

Table 1. Contd.

\begin{tabular}{|c|c|c|c|c|c|c|c|c|c|c|}
\hline \multirow{2}{*}{$\begin{array}{l}\text { Diseases occurred in } \\
\text { the different systems }\end{array}$} & \multicolumn{4}{|c|}{ Age Grouping (Year) } & \multicolumn{2}{|c|}{ Sex } & \multicolumn{3}{|c|}{ Season } & \multirow[b]{2}{*}{ Total } \\
\hline & $\begin{array}{l}0-2 \\
\left(A_{1}\right)\end{array}$ & $\begin{array}{l}2-5 \\
\left(A_{2}\right)\end{array}$ & $\begin{array}{l}5-8 \\
\left(A_{3}\right)\end{array}$ & $\begin{array}{l}8-10 \\
\left(\mathrm{~A}_{4}\right)\end{array}$ & $\mathrm{M}$ & F & Summer & Rainy & Winter & \\
\hline \multicolumn{11}{|l|}{ Infectious diseases } \\
\hline Babesiosis & 6 & 25 & 0 & 0 & 15 & 16 & 3 & 28 & 0 & 31 \\
\hline Black quarter & 23 & 0 & 0 & 0 & 5 & 18 & 0 & 23 & 0 & 23 \\
\hline Calf scour & 3 & 0 & 0 & 0 & 1 & 2 & 0 & 3 & 0 & 3 \\
\hline Coccidiosis & 16 & 0 & 0 & 0 & 11 & 5 & 4 & 5 & 7 & 16 \\
\hline Dermatophilosis & 14 & 0 & 0 & 0 & 6 & 8 & 10 & 4 & 0 & 14 \\
\hline Eph. Fever & 107 & 16 & 24 & 0 & 17 & 130 & 78 & 35 & 34 & 147 \\
\hline FMD & 35 & 10 & 0 & 1 & 11 & 35 & 0 & 45 & 1 & 46 \\
\hline Foot rot & 5 & 0 & 0 & 0 & 5 & 0 & 0 & 4 & 1 & 5 \\
\hline Navel ill & 10 & 0 & 0 & 0 & 7 & 3 & 0 & 2 & 8 & 10 \\
\hline Papillomatosis & 12 & 1 & 0 & 0 & 2 & 11 & 0 & 9 & 4 & 13 \\
\hline Total & 231 & 52 & 24 & 1 & 80 & 228 & 95 & 158 & 55 & 308 \\
\hline \multicolumn{11}{|c|}{ Deficiency \& Metabolic diseases } \\
\hline Agalactia & 0 & 42 & 4 & 0 & 0 & 46 & 8 & 20 & 18 & 46 \\
\hline Milk fever & 0 & 12 & 0 & 1 & 0 & 13 & 0 & 4 & 9 & 13 \\
\hline Total & 0 & 54 & 4 & 1 & 0 & 59 & 8 & 24 & 27 & 59 \\
\hline Dog bite & 1 & 0 & 0 & 0 & 0 & 1 & 1 & 0 & 0 & 1 \\
\hline
\end{tabular}

Season wise diseases and disorders in cattle were presented in the Table $1 \& 4$. The results obtained from the study exerted that diseases and disorders of cattle were more prominent in the rainy season than that of summer and winter ones. It was also observed in the study that all of the diseases were not recorded in all the year round such as 17 no. diseases namely Dysentary, Abortion, Posthitis, Retention of placenta, Arthritis, Broken horn, Abscess, Hump sore, Corneal opacity, Keratitis, Black quarter, Calf scour, FMD, Foot rot, Navel ill, Papillomatosis and Milk fever were not recorded in summer. On the other hand 12 no. of diseases such as Dysentary, Fasciliosis, Pneumonia, Abortion, Metritis, Dystocia, Retention of placenta, Arthritis, Broken horn, Wound, Corneal opacity and Dog bite were not affect the cattle during the rainy season in the studied hill area whereas winter is the more favorable for cattle diseases hence in this time only 10 no. of diseases namely Dystocia, Posthitis, Wound, Hump sore, Keratitis, Babesiosis, Black quarter, Calf scour, Dermatophilosis and dog bite were not recorded for the period 2006-2010 (Table1).

Table 2. Cross tabulation of diseases and different types of cattle

\begin{tabular}{|c|c|c|c|c|c|c|}
\hline \multirow{2}{*}{ Diseases } & \multicolumn{4}{|c|}{ Types of Cattle } & \multirow{2}{*}{ Total } & \multirow{2}{*}{$\begin{array}{c}\text { Chi-square } \\
\text { value }\end{array}$} \\
\hline & Calf & Heifer & Bull & Cow & & \\
\hline Gastrointestinal system & 312 & 440 & 117 & 540 & 1409 & \\
\hline Respiratory system & 42 & 6 & 1 & 1 & 50 & \\
\hline Reproductive system & 0 & 3 & 1 & 215 & 219 & \\
\hline Musculoskeletal system & 1 & 0 & 1 & 17 & 19 & \\
\hline Integumentary system & 50 & 19 & 10 & 39 & 118 & $717.97^{* *}$ \\
\hline Eye \& Ear & 1 & 0 & 13 & 2 & 16 & \\
\hline Infectious diseases & 81 & 129 & 37 & 61 & 308 & \\
\hline Deficiency \& Metabolic diseases & 0 & 0 & 0 & 59 & 59 & \\
\hline Dog bite & 0 & 1 & 0 & 0 & 1 & \\
\hline Total & 487 & 598 & 180 & 934 & 2199 & \\
\hline
\end{tabular}

** There is statistically highly significant relation between diseases and different types of cattle. 
Table 3. Cross tabulation of diseases and sex $(\mathrm{m} / \mathrm{f})$ for cattle

\begin{tabular}{|lllll|}
\hline \multirow{2}{*}{ Diseases } & \multicolumn{2}{c}{ Sex (M/F) } & Total & $\begin{array}{c}\text { Chi-square } \\
\text { value }\end{array}$ \\
\cline { 2 - 4 } & $\mathrm{M}$ & $\mathrm{F}$ & 1409 & \\
\hline Gastrointestinal system & 239 & 1170 & 50 & \\
Respiratory system & 9 & 41 & 219 & $124.15^{* *}$ \\
Reproductive system & 1 & 218 & 19 & \\
Musculoskeletal system & 1 & 18 & 16 & \\
Integumentary system & 22 & 96 & 308 & 59 \\
Diseases of sense organs & 14 & 2 & 1 & \\
Infectious diseases & 70 & 238 & 2199 & \\
Deficiency \& Metabolic & 0 & 59 & 1 & \\
Dog bite & 0 & 1843 & & \\
Total & 356 & &
\end{tabular}

** There is statistically highly significant relation between diseases and sex for cattle.

Table 4. Cross tabulation of diseases and season for cattle

\begin{tabular}{|llllll|}
\hline \multirow{2}{*}{ Diseases } & \multicolumn{3}{c}{ Season } & Total & $\begin{array}{c}\text { Chi-square } \\
\text { value }\end{array}$ \\
\cline { 2 - 5 } & Summer & Rainy & Winter & & 1409 \\
Gastrointestinal system & 349 & 601 & 459 & 19 \\
Respiratory system & 5 & 9 & 5 & 118 \\
Reproductive system & 29 & 49 & 40 & 219 & $53.02^{* *}$ \\
Musculoskeletal system & 55 & 86 & 78 & 59 & 16 \\
Integumentary system & 8 & 24 & 27 & 308 & 50 \\
Diseases of sense organs & 3 & 8 & 5 & 1 & \\
Infectious diseases & 95 & 158 & 55 & 2199 \\
Deficiency \& Metabolic & 22 & 9 & 19 & \\
Dog bite & 1 & 0 & 0 & \\
Total & 567 & 944 & 688 & \\
\hline
\end{tabular}

** There is statistically highly significant relation between diseases and seasons for cattle.

Age, sex and season wise distribution of diseases and disorders observed in different systems of goat

Age wise distribution of diseases and disorders in goat as per systems have been summarized and presented in Table 5. All 6 cases of arthritis were found in age group $A_{1}$ in case of goat (Table $5 \& 8$ ). Deficiency and metabolic diseases are more common in age group $\mathrm{A}_{1}$. Diseases of integumentary system (Skin diseases) were found more common 282 cases (74.80\%) in age group $A_{1}$. Sex wise distribution of diseases and disorders in goat has been summarized and presented in Table 5.The diseases of gastrointestinal system were commonly found in female (516) than that of male (293). There is statistically highly significant relation between diseases and sex for goat (Table 9). In 9 cases diseases infestation was observed as single ones either the summer or rainy or winter in the studied areas of Bangladesh. Data on diseases infestation in goat related with season revealed that most of the diseases occurred during the rainy season than that of summer and winter ones except in case of deficiency and metabolic diseases as well as diseases related to integumentary system (Table 5). There is also statistically highly significant relation between diseases and season for goat (Table 10).

\section{Age, sex and season wise distribution of diseases and disorders observed in different systems of sheep}

In the study 45 sheep of different aged were recorded for investigating of 6 no. of enlisted diseases related with gastrointestinal system, respiratory systems as well as metabolic and deficiency (Table 6). It was observed that, sheep of 0 -2 years aged were more susceptible than that of older aged. The study also revealed that sheep of older aged gave fully negative response against the diseases of pneumonia as well as zinc deficiency (Table 5). Based on sex wise diseases and disorders in sheep as per systems it can be stated that there were not strict differences between male and female as observed in the Table 6. Accordingly the findings of cattle and goat it was also dominant that sheep in the hill areas were mostly affected in the rainy season than that of other to seasons namely summer winter (Table 6). There is also statistically highly significant relation between diseases in sheep in relation with age, sex and seasons (Table 8-10). 


\section{H. Ali and Others}

Table 5. Distribution of diseases and disorders in goat observed in age, sex and season wise

\begin{tabular}{|c|c|c|c|c|c|c|c|c|c|}
\hline \multirow{2}{*}{$\begin{array}{l}\text { Diseases occurred in the } \\
\text { different systems }\end{array}$} & \multicolumn{3}{|c|}{ Age Grouping (Year) } & \multicolumn{2}{|c|}{ Sex } & \multicolumn{3}{|c|}{ Season } & \multirow{2}{*}{ Total } \\
\hline & $0-2\left(\mathrm{~A}_{1}\right)$ & $2-5\left(\mathrm{~A}_{2}\right)$ & $5-8\left(A_{3}\right)$ & $\mathrm{M}$ & $\mathrm{F}$ & Summer & Rainy & Winter & \\
\hline \multicolumn{10}{|l|}{ Gastrointestinal system } \\
\hline Enteritis & 22 & 5 & 0 & 8 & 19 & 1 & 18 & 8 & 27 \\
\hline Indigestion & 20 & 14 & 0 & 20 & 14 & 12 & 15 & 7 & 34 \\
\hline PPR & 48 & 22 & 0 & 16 & 54 & 0 & 56 & 14 & 70 \\
\hline Worm infestation & 328 & 348 & 2 & 249 & 429 & 180 & 269 & 229 & 678 \\
\hline Total & 418 & 389 & 2 & 293 & 516 & 193 & 358 & 258 & 809 \\
\hline \multicolumn{10}{|l|}{ Respiratory system } \\
\hline Aspiration pneumonia & 1 & 2 & 0 & 1 & 2 & 0 & 1 & 2 & 3 \\
\hline pneumonia & 18 & 3 & 0 & 5 & 16 & 5 & 6 & 10 & 21 \\
\hline Pneumonitis & 122 & 93 & 0 & 77 & 138 & 64 & 80 & 71 & 215 \\
\hline Total & 141 & 98 & 2 & 83 & 156 & 69 & 87 & 83 & 239 \\
\hline \multicolumn{10}{|l|}{ Reproductive system } \\
\hline Abortion & 4 & 0 & 0 & 0 & 4 & 3 & 1 & 0 & 4 \\
\hline Cervicitis & 0 & 5 & 0 & 0 & 5 & 1 & 3 & 1 & 5 \\
\hline Mastitis & 1 & 0 & 0 & 0 & 1 & 0 & 0 & 1 & 1 \\
\hline Retention of placenta & 0 & 3 & 0 & 0 & 3 & 0 & 3 & 0 & 3 \\
\hline Total & 5 & 8 & $\mathbf{0}$ & $\mathbf{0}$ & 13 & 4 & 7 & 2 & 13 \\
\hline \multicolumn{10}{|l|}{ Musculoskeletal system } \\
\hline Arthritis & 6 & 0 & 0 & 6 & 0 & 0 & 6 & 0 & 6 \\
\hline \multicolumn{10}{|l|}{ Integumentary system } \\
\hline Abscess & 10 & 16 & 0 & 1 & 25 & 3 & 6 & 17 & 26 \\
\hline Contagious ecthyma & 30 & 7 & 0 & 12 & 25 & 2 & 26 & 9 & 37 \\
\hline Lice infestatios & 16 & 0 & 0 & 16 & 0 & 1 & 8 & 7 & 16 \\
\hline Manage & 91 & 37 & 0 & 11 & 117 & 31 & 44 & 53 & 128 \\
\hline Myiasis & 32 & 10 & 10 & 27 & 25 & 9 & 22 & 21 & 52 \\
\hline Total & 179 & 70 & 10 & 67 & 192 & 46 & 106 & 107 & 259 \\
\hline \multicolumn{10}{|l|}{ Diseases of sense organs } \\
\hline Conjunctivitis & 13 & 0 & 0 & 10 & 3 & 1 & 4 & 8 & 13 \\
\hline Corneal opacity & 0 & 3 & 0 & 0 & 3 & 0 & 3 & 0 & 3 \\
\hline Keratitis & 8 & 20 & 0 & 0 & 28 & 13 & 5 & 10 & 28 \\
\hline Otitis & 0 & 2 & 0 & 2 & 0 & 2 & 0 & 0 & 2 \\
\hline Total & 21 & 25 & $\mathbf{0}$ & 12 & 34 & 16 & 12 & 18 & 46 \\
\hline \multicolumn{10}{|l|}{ Infectious diseases } \\
\hline Coccidiosis & 0 & 3 & 0 & 0 & 3 & 0 & 0 & 3 & 3 \\
\hline Navel ill & 7 & 0 & 0 & 5 & 2 & 3 & 2 & 2 & 7 \\
\hline Total & 7 & 3 & $\mathbf{0}$ & 5 & 5 & 3 & 2 & 5 & 10 \\
\hline \multicolumn{10}{|c|}{ Deficiency \& Metabolic diseases } \\
\hline Agalactia & 2 & 0 & 0 & 0 & 2 & 2 & 0 & 0 & 2 \\
\hline Zinc deficiency & 12 & 3 & 0 & 10 & 5 & 11 & 4 & 0 & 15 \\
\hline Total & 14 & 3 & $\mathbf{0}$ & 10 & 7 & 13 & 4 & $\mathbf{0}$ & 17 \\
\hline Poisoning & 4 & 0 & 0 & 1 & 3 & 0 & 4 & 0 & 4 \\
\hline
\end{tabular}

Age, sex and season wise distribution of diseases and disorders observed in different systems of pig

Age wise distribution of diseases and disorders in pig as per systems have been summarized and presented in Table 7. All the enlisted 7 cases of diseases, diseases related with gastrointestinal system, integumentery system and infectious were more prominent in age group 2-5 years. Sex wise distribution of diseases and disorders in pig has been summarized and presented also in Table 7.The diseases of gastrointestinal system were commonly found in female (137) than that of male (61). This phenomenon is also applicable in case of diseases related with integumentery systems and infectious but negatively in case of diseases recorded in the respirations system of pig (Table 7). Data on diseases infestation in pig related with season revealed that most of the diseases occurred 
during the rainy season than that of summer and winter ones except in case of gastrointestinal system where the diseases occurrences were same in rainy and winter seasons (Table 5). There is also statistically highly significant relation between diseases in pig in relation with age, sex and seasons (Table 8-10).

Table 6. Distribution of diseases and disorders in sheep observed in age, sex and season wise

\begin{tabular}{|c|c|c|c|c|c|c|c|c|}
\hline \multirow{2}{*}{$\begin{array}{l}\text { Diseases occurred in the } \\
\text { different systems }\end{array}$} & \multicolumn{2}{|c|}{ Age Grouping (Year) } & \multicolumn{2}{|c|}{ Sex } & \multicolumn{3}{|c|}{ Season } & \multirow{2}{*}{ Total } \\
\hline & $0-2\left(A_{1}\right)$ & $2-5\left(\mathrm{~A}_{2}\right)$ & $\mathrm{M}$ & $\mathrm{F}$ & Summer & Rainy & Winter & \\
\hline \multicolumn{9}{|l|}{ Gastrointestinal system } \\
\hline Dysentery & 9 & 0 & 8 & 1 & 2 & 2 & 5 & 9 \\
\hline Enteritis & 10 & 0 & 3 & 7 & 1 & 6 & 3 & 10 \\
\hline PPR & 4 & 3 & 0 & 7 & 0 & 6 & 1 & 7 \\
\hline Worm infestation & 10 & 6 & 9 & 7 & 2 & 6 & 8 & 16 \\
\hline Total & 33 & 9 & 20 & 22 & 5 & 20 & 17 & 42 \\
\hline Respiratory system & & & & & & & & \\
\hline $\begin{array}{l}\text { Pneumonia } \\
\text { Metabolic \& deficiency }\end{array}$ & 1 & 0 & 1 & 0 & 0 & 0 & 1 & 1 \\
\hline Zinc deficiency & 2 & 0 & 1 & 1 & 2 & 0 & 0 & 2 \\
\hline
\end{tabular}

Table 7. Distribution of diseases and disorders in pig observed in age, sex and season wise

\begin{tabular}{|c|c|c|c|c|c|c|c|c|c|}
\hline \multirow{2}{*}{$\begin{array}{l}\text { Diseases occurred in the } \\
\text { different systems }\end{array}$} & \multicolumn{3}{|c|}{ Age Grouping (Year) } & \multicolumn{2}{|c|}{ Sex } & \multicolumn{3}{|c|}{ Season } & \multirow{2}{*}{ Total } \\
\hline & $0-2\left(A_{1}\right)$ & $2-5\left(A_{2}\right)$ & $5-8\left(A_{3}\right)$ & $\mathrm{M}$ & $\mathrm{F}$ & Summer & Rainy & Winter & \\
\hline \multicolumn{10}{|l|}{ Gastrointestinal system } \\
\hline Enteritis & 11 & 0 & 0 & 2 & 9 & 3 & 3 & 5 & 11 \\
\hline Worm infestation & 62 & 110 & 15 & 59 & 128 & 59 & 65 & 63 & 187 \\
\hline Total & 73 & 110 & 15 & 61 & 137 & 62 & 68 & 68 & 198 \\
\hline \multicolumn{10}{|l|}{ Respiratory system } \\
\hline Aspiration pneumonia & 0 & 1 & 0 & 0 & 1 & 0 & 1 & 0 & 1 \\
\hline pneumonia & 18 & 0 & 0 & 14 & 4 & 0 & 12 & 6 & 18 \\
\hline Pneumonitis & 21 & 0 & 0 & 15 & 6 & 8 & 7 & 6 & 21 \\
\hline Total & 39 & 1 & $\mathbf{0}$ & 29 & 11 & 8 & 20 & 12 & 40 \\
\hline \multicolumn{10}{|l|}{ Integumentary system } \\
\hline Wound & 0 & 5 & 0 & 0 & 5 & 5 & 0 & 0 & 5 \\
\hline \multicolumn{10}{|l|}{ Infectious diseases } \\
\hline Swine erysipelas & 70 & 28 & 0 & 33 & 65 & 13 & 48 & 37 & 98 \\
\hline
\end{tabular}

Table 8. Cross tabulation of diseases and different type of small ruminants

\begin{tabular}{|c|c|c|c|c|c|}
\hline \multirow[t]{2}{*}{ Diseases } & \multicolumn{3}{|c|}{ Type of small ruminants } & \multirow{2}{*}{ Total } & \multirow{2}{*}{$\begin{array}{c}\text { Chi-square } \\
\text { value }\end{array}$} \\
\hline & Goat & Sheep & Pig & & \\
\hline Gastrointestinal system & 809 & 42 & 198 & 1049 & \\
\hline Respiratory system & 239 & 1 & 40 & 280 & \\
\hline Reproductive system & 13 & 0 & 5 & 18 & \\
\hline Musculoskeletal system & 6 & 0 & 0 & 6 & \\
\hline Integumentary system & 259 & 0 & 0 & 259 & $47614^{* *}$ \\
\hline Eye \& Ear & 46 & 0 & 0 & 46 & 4/0.14 \\
\hline Infectious diseases & 10 & 0 & 98 & 108 & \\
\hline Deficiency \& Metabolic & 17 & 2 & 0 & 19 & \\
\hline Miscellaneous & 4 & 0 & 0 & 4 & \\
\hline Total & 1403 & 45 & 341 & 1789 & \\
\hline
\end{tabular}

** There is statistically highly significant relationship between type of small ruminants and diseases. 


\section{H. Ali and Others}

Table 9. Cross tabulation of diseases and sex (m/f) for small ruminants

\begin{tabular}{|c|c|c|c|c|}
\hline \multirow{2}{*}{ Diseases } & \multicolumn{2}{|c|}{ Sex } & \multirow{2}{*}{ Total } & \multirow{2}{*}{$\begin{array}{c}\text { Chi-square } \\
\text { value }\end{array}$} \\
\hline & $\mathrm{M}$ & $\mathrm{F}$ & & \\
\hline Gastrointestinal system & 372 & 677 & 1049 & \multirow{10}{*}{$48.13^{* *}$} \\
\hline Infectious diseases & 34 & 74 & 108 & \\
\hline Respiratory system & 119 & 161 & 280 & \\
\hline Reproductive system & 0 & 18 & 18 & \\
\hline Musculoskeletal system & 6 & 0 & 6 & \\
\hline Integumentary system & 92 & 167 & 259 & \\
\hline Diseases of sense organs & 15 & 31 & 46 & \\
\hline Deficiency \& Metabolic & 16 & 3 & 19 & \\
\hline Miscellaneous & 0 & 4 & 4 & \\
\hline Total & 654 & 1135 & 1789 & \\
\hline
\end{tabular}

** There is statistically highly significant relationship between sex of small ruminants and diseases

Table 10. Cross tabulation of diseases and season for small ruminants

\begin{tabular}{|c|c|c|c|c|c|}
\hline \multirow{2}{*}{ Diseases } & \multicolumn{3}{|c|}{ Season } & \multirow{2}{*}{ Total } & \multirow{2}{*}{$\begin{array}{c}\text { Chi-square } \\
\text { value }\end{array}$} \\
\hline & Summer & Rainy & Winter & & \\
\hline Gastrointestinal system & 260 & 446 & 343 & 1049 & \multirow{10}{*}{$74.94^{* *}$} \\
\hline Respiratory system & 0 & 6 & 0 & 6 & \\
\hline Reproductive system & 46 & 106 & 107 & 259 & \\
\hline Musculoskeletal system & 9 & 7 & 2 & 18 & \\
\hline Integumentary system & 15 & 4 & 0 & 19 & \\
\hline Diseases of sense organs & 16 & 12 & 18 & 46 & \\
\hline Infectious diseases & 16 & 50 & 42 & 108 & \\
\hline Deficiency \& Metabolic & 77 & 107 & 96 & 280 & \\
\hline Miscellaneous & 0 & 4 & 0 & 4 & \\
\hline Total & 439 & 742 & 608 & 1789 & \\
\hline
\end{tabular}

** There is statistically highly significant relation between diseases and seasons for small ruminants.

\section{Diseases in cattle, goat, sheep and pig}

Among individual diseases the prevalence of worm infestation was highest followed by 5 diseases were more prevalent viz. enteritis, indigestion, pneumonia and pneumonitis, mange and ephemeral fever. The prevalence of other diseases was comparatively low. Among diseases of different systems those affecting reproductive system constituted highest occurrence is anestrous. This might be due to mainly for nutritional deficiency, infectious diseases, ovarian cyst and failure to heat detection by owners. The occurrence of diseases was found to be more in female than male due to the presence of higher number of female animals in the study area. The prevalence of mastitis was $2.3 \%$ in the present study .The higher rates $18.6 \%$ had been recorded previously (Prodan et al., 1996) and (Rahman et al., 1996). Mastitis was also found more in rainy season in the study which was fully supported by Singh et al. (1996). Metritis was higher in $\mathrm{A}_{2}$ age group. Rainy season was favorable for metritis which was coincided with previous study reported by (Marskusfeld, 1984). It is possibly due to fatness of cows, nutritional deficiency specially selenium, Vit-E and heavy grain feeding prior to parturition. The prevalence rate of abortion 0.2 $\%$ was fully coincided (Chourewar et al., 2002). Abortion might be due to faulty management of pregnant cows, slippery floor, unhygienic environment of farm and other infectious diseases. Among viral diseases FMD was found high due to movement of cattle for different purposes. The prevalence of ephemeral fever $3.7 \%$ in the present study was merely resemble with $2.6 \%$ reported by Yearuham et al. (2007).

Based on the results of this retrospective epidemiologic study of animal diseases of Khagrachari Sadar Veterinary Hospital, the most important 5 diseases were found: worm infestation, pneumonia and pneumonitis, enteritis, mange and ephemeral fever. Occurrence of the diseases was higher in female animals than male. Animals aged between $0-2$ years are more likely to be affected by the diseases and disorders. More diseases were 
reported in the rainy season. Gastrointestinal diseases were found more common. Retrospective epidemiologic analysis of diseases for a period of 15 years or more will help to identify risk factors of diseases. Identification of risk factors of diseases will help to initiate efficient control program.

\section{REFERENCES}

1. Chourewar S, Ali SZ and Kuralkar SV (2002). Incidence of reproductive disorders in crossbred cows. Indian Journal of Dairy Science 55(5): 313-315.

2. DLS (2010). Personal communication With Project Director, Animal Health Care, Management and Expansion Project, DLS, Dhaka.

3. FAO (2007). FAO production Year Book, Food and Agricultural organization of the USA, Rome, Italy. Vol 51.

4. Kamaruddin KM (2003). Goat farming as a means of poverty alleviation. Proceeding of the BSVER symposium, Goats farming in Bangladesh; Problems and prospects. BAU. Bangladesh society for veterinary education research, BSVER Pub. No. 25 P- 26-34.

5. Markusfeld O (1984). Factors responsible for post parturient metritis in dairy cattle. Veterinary Record 114: 539.

6. Prodhan MAM, Kamal AHM and Mahbub-E-Elahi ATM (1996). Prevalence of subclinical mastitis in cows of Baghabari Milk-shed Area. Bangladesh Veterinary Journal 30(1-2): 59-61.

7. Rahman MS, Nooruddin M and Rahman MM (1996). Prevalence and distribution of mastitis in crossbred and exotic dairy cows. Bangladesh Veterinarian 14(1-2): 1-4.

8. Singh KB, Nauiyal DC, Oberoi MS and Baxi KK (1996). Seasonal occurrence of clinical mastitis. Indian Journal of Dairy Science 49(8): 534-536.

9. Yeruham L, Gur Y and Braverman Y (2007). Retrospective epidemiological investigation of an outbreak of Bovine ephemeral fever in 1991 affecting dairy cattle herds on the Mediterranean coastal plain. The Veterinary Journal, Israel 173(1):190-193.

10. Rahman MK, Rahman MB, Siddiky MNA, Kafi MA, Islam MA and Choudhury KA (2004c). Efficacy of formalin killed fowl cholera vaccine in experimentally immunized Fayoumi chickens. Bangladesh Journal of Veterinary Medicine 2: 23-25. 